\title{
Economic Potential of Sweet Sorghum for Ethanol Production in South Florida ${ }^{1}$
}

\author{
Zane R. Helsel and José Álvarez ${ }^{2}$
}

\section{Introduction}

Sweet sorghum [Sorghum bicolor (L.) Moench] has been designated by the United States Department of Energy as a potentially viable biofuel crop for the Southeast. There are numerous reasons for considering sweet sorghum as a bioenergy crop in Florida. It can be established as part of a rotation, with the potential of more than 400 gallons of ethanol per acre in four months, compared to sugarcane, with the potential of 700 gallons of ethanol per acre in twelve months. Other reports have also noted less water and fertilizer inputs needed for sweet sorghum as compared to sugarcane (Bradford 2008; Farmers Growing Fuel 2009; and Vecchiet 2010). The grain and bagasse have additional uses and revenue potential, but are not addressed in this publication.

In Florida, numerous businesses have developed technologies to convert crops like sweet sorghum into energy.

Obviously, they see a comparative advantage in the long, warm, growing season in the "Sunshine State." The University of Florida's Institute of Food and Agricultural Sciences (UF/IFAS) is currently involved in a multitude of research projects in this area, and the Florida Institute for Sustainable Energy at the University of Florida highlights many of these studies on its website at http://www.energy.ufl.edu/.
The purpose of this publication is to evaluate the economic potential of producing sweet sorghum as an annual bioenergy crop in the state of Florida. This crop has generated attention as a feedstock for ethanol production since the 1970s. For nearly a century, it has been grown in the midsouth to make syrup and other products. Sweet sorghum is a summer annual crop, producing a harvestable crop in 110-135 days. Several studies have shown it to produce well even on droughty low-fertility soils. In South Florida, preliminary research at the UF/IFAS Everglades Research and Education Center has shown that sweet sorghum can produce a harvestable ratoon crop if the plant (first) crop is planted by May, and even earlier than this date, higher ratoon yields can be produced. The stalks of sweet sorghum have a high concentration of soluble sugars, approximately 80 percent that of sugarcane, and their bagasse can be utilized, much like sugarcane's, for direct combustion or for potential conversion to ethanol through cellulosic conversion processes. While there is no significant commercial production of sweet sorghum at present in Florida, grain sorghum and forage sorghums for silage (very similar crops agronomically) are grown in the state.

Other EDIS publications have reviewed the agronomic aspects of sweet sorghum (http://edis.ifas.ufl.edu/AG298) and the economics of energycane (http://edis.ifas.ufl.edu/ SC089) and sugarcane (http://edis.ifas.ufl.edu/SC090), which serve as a helpful background in evaluating the

1. This is EDIS document FE896, a publication of the Food and Resource Economics Department, Florida Cooperative Extension Service, Institute of Food and Agricultural Sciences, University of Florida, Gainesville, FL. Published August 2011. Please visit the EDIS website at http://edis.ifas.ufl.edu.

2. Zane R. Helsel, courtesy professor, Agronomy Department, University of Florida, Everglades Research and Education Center, Belle Glade, FL, and extension specialist, Department of Plant Biology and Pathology, Rutgers University, New Brunswick, NJ; José Álvarez, emeritus professor, Food and Resource Economics Department, University of Florida, Everglades Research and Education Center, Belle Glade, FL; Florida Cooperative Extension Service, Institute of Food and Agricultural Sciences, University of Florida, Gainesville, FL 32611 
results presented in this publication. The following budget and analyses help indicate where further research may be necessary to improve future economic potential and to help potential producers determine whether they should consider early implementation of sweet sorghum production for biofuel.

\section{Assumption}

It was assumed in this study that sweet sorghum is grown on a 640-acre farm (usually referred to as "one section"). The farm is broken down by section for management decisions. Because the hypothetical farm is assumed to be already established, there are no development costs to defray. The soil is classified as mineral (sand) and subdivided into 1640 -acre blocks. There are 14 one-halfmile-long field ditches ( 7 miles total), and 2 one-mile-long seepage canals. Therefore, after deducting 65 acres of roads, canals, and ditches, net acreage is 575 acres. It was also assumed that sweet sorghum could be ratooned for an additional crop in the calendar year, or the first crop only could be rotated with vegetables or inserted as a fallow crop for sugarcane. Various costs and production estimates come from research data, local practices, and/or custom rates in the related corn silage and sugarcane industries. Because numerous costs change with purchased product prices (fertilizers, pesticides, fuel, etc.), growers and others reading this publication are encouraged to utilize their own updated costs in the budgets to follow.

Numerous fertilizer and/or pesticide operations were assumed to be combined with each other or with tillage operations. Late applications for pest control may increase application costs above those used here. Labeled pesticides for sweet sorghum are limited and, although certain pesticides were chosen as examples for cost determination, no recommendations are given. Other choices may result in higher or lower costs. Biomass yields are assumed at 30 tons per acre for the first crop and 15 tons per acre for the second crop, using the average of 22.5 tons in the budget calculations. Sweet sorghum was assumed to be deheaded two weeks prior to harvest (for the purpose of boosting sugar yields), and then harvested with a corn silage harvester and transported by truck 10 miles to the processing plant. Although no long-term production or processing data exist in the United States, research at UF/IFAS and reports from countries like India, where commercial processing has taken place, suggest that sweet sorghum could conservatively yield 14 gallons of ethanol per wet ton (compared to 19.5 for sugarcane) and could be processed at 55 cents per gallon (this figure does not include all startup capital costs). This cost is several cents higher than the cost for sugarcane, primarily because of the greater volume of sweet sorghum biomass processed to produce similar levels of ethanol (Morris 2008). Finally, it was assumed that the bagasse would be combusted, as in the sugarcane industry, for heat and electricity to run the biofuel plant, and that the amount would be adequate to cover those energy and other related costs of handling the bagasse.

\section{Results}

An enterprise budget indicates that it would cost about $\$ 1,620$ per acre to produce a plant (first) and a ratoon (second) crop of sweet sorghum for energy on the mineral soils of South Florida (Table 1).

A break-down by production stages includes fallow land maintenance, land preparation, planting, cultural practices, miscellaneous expenses, interest, harvesting activities, and overhead expenses. Table 2 presents a sensitivity analysis, showing a 5, 10, and 15 percent increase and decrease in cost by activity.

Harvest and transportation at 37 percent, followed by fertilizer and chemical products at 31 percent of total costs, account for over two-thirds of total production expenses and are directly related to energy consumption. These costs can increase significantly, for example, if transport miles are greater and energy prices rise proportionately. Fertilizer prices have risen in recent years with energy prices and continue to fluctuate. So too can fertilizer rates vary because of some potential loss on sands due to heavy rainfall periods. There are other expenses involving fuel used in tillage, planting, and cultivation that also consume energy directly, thus fluctuating with energy prices.

These results present a dilemma. The high expenses for energy use shown in the budget must be surpassed by the energy produced by the crop. The budget assumes a total yield of 45 tons per acre for the plant (30 tons/acre) and ratoon (15 tons/acre) crops (average of 22.5 tons per crop as listed in Table 1 for ease of analysis). Assuming 14 gallons of ethanol are derived from fermentation per wet ton, a yield of over 600 gallons of ethanol could be realized from these 45 tons. Breakeven cost evaluations (Table 3) indicate that at the base yield of 45 tons per acre, ethanol would need to have a value of at least $\$ 3.12$ per gallon for the ethanol producer to break even at this yield level when two crops of sweet sorghum are harvested.

The previous analysis assumed that two crops of sweet sorghum were grown in one year and that they were harvested and transported as corn for silage, which conveys 
very high transportation costs. However, it has been argued that the technology for harvesting and transporting sugarcane can be used for sweet sorghum. That fact would lower the breakeven prices considerably. For example, when sugarcane technology is assumed, breakeven prices per gallon of ethanol at $31.5,45.0$, and 58.5 tons per acre would decrease from $\$ 3.83$ to $\$ 3.27$, from $\$ 3.12$ to $\$ 2.58$, and from $\$ 2.74$ to $\$ 2.21$, respectively (Figure 1 ).

In addition, where only the plant crop was grown in rotation with winter vegetables or in the traditional fallow period of sugarcane, breakeven prices per gallon would also decrease because certain fixed costs are proportionally ascribed to the other crop. In this case, breakeven prices at yields of 20,30 , and 40 tons would result in $\$ 3.86, \$ 3.07$, and $\$ 2.67$ per gallon, respectively, using the current technology, and in $\$ 3.32, \$ 2.54$, and $\$ 2.15$, respectively, when sugarcane technology is used (Figure 1).

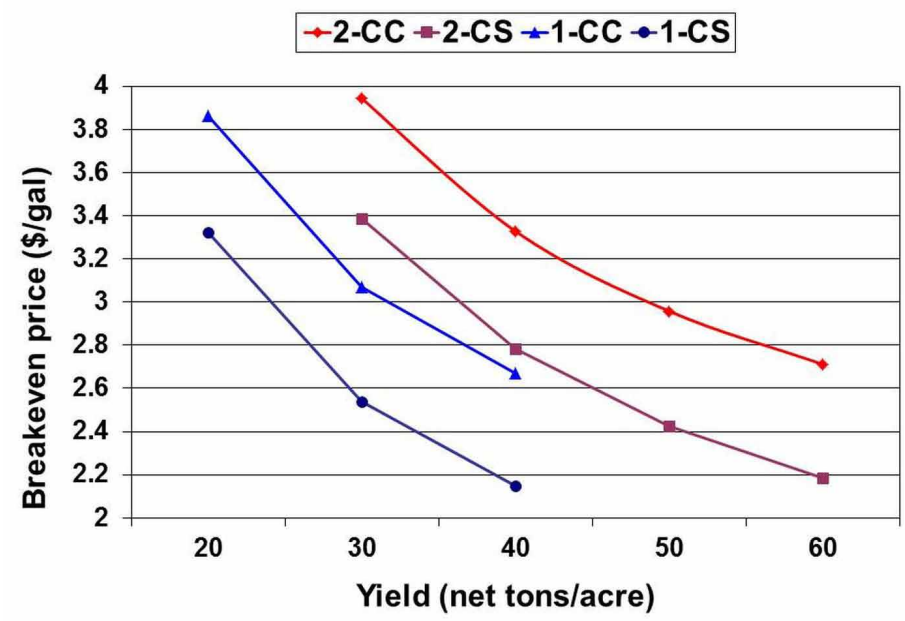

Figure 1. Breakeven prices of ethanol from sweet sorghum using sugarcane's harvest and transportation methods (CS) versus custom rates on corn silage harvest and transportation (CC) for the 2-cut and 1 -cut systems, at 55 cents per gallon processing cost

In most cases, these breakeven prices are higher than predicted for sugarcane produced on Florida's mineral soils for ethanol (approximately \$2.20) (see http://edis.ifas.ufl. edu/SC090). Upon analysis of the differences, sugarcane has a higher sugar percentage; does not need to be planted each year; and of particular interest, the harvest and transport costs are lower. This is likely a result of the long-term institutionalized costs in the sugarcane industry verses custom harvest and transportation rates used for sweet sorghum which were based on corn silage industry information.

Figure 1 indicates that if sweet sorghum could be harvested and handled similarly to sugarcane (which should be possible), the breakeven prices in the 2 - and 1-crop systems would be between 50 and 55 cents per gallon lower than those for sweet sorghum using custom rates, although still not similar in most cases to the $\$ 2.20$ per gallon estimated for sugarcane at the yield of 32 tons per acre.

In summary, if sweet sorghum can be produced as a rotation crop and some of the practices in the sugarcane industry can be utilized, sweet sorghum can become profitable as ethanol prices rise. For this expectation to be fully realized, however, improved varieties with higher yields of sugar and with pest resistance, fertilizer nutrient efficiencies, and alternative utilizations (grain, bagasse, vinasse, etc.) will need further research and development to reduce energy and dollar investments in producing sweet sorghum, boost revenue, and increase overall profitability.

\section{References}

Bradford, V.E. 2008. An advanced feedstock for ethanol: Sweet sorghum is crop to fuel the future. Sugar Journal 2008 (January): 16-20. http://www.SugarJournal.com

E85Prices.com. http://E85prices.com/florida.html

Farmers Growing Fuel (FGF). 2009. Sweet sorghum: The best crop for ethanol production, now, and for the foreseeable future. http://www.farmersgrowingfuel.com/ best-crop-for-ethanol.php

Frosch, B.J. 2008. Estimating and comparing alternative ethanol processes and feedstock sources. In Proceedings of the Transition to a Bio Economy Conferences, Integration of Agricultural and Energy Systems Conference, Atlanta, GA (February). http://ideas.repec.org/p/ags/fftrin/48709.html

Morris, B.D. 2008. Economic feasibility of ethanol production from sweet sorghum juice in Texas. M.S. Thesis, Texas A\&M University, College Station, TX (December).

Vecchiet, A. 2010. Advantages of sweet sorghum for bioethanol production. European Community for Sweet Sorghum \& Ethanol. http://esse-community.eu/articles/advantages-of-sweet-sorghum-for-bioethanol-production-2/

\section{Sources of Additional Information}

Alvarez, J. and Z.R. Helsel. 2001. Economic feasibility of biofuel crops in Florida: Energycane on mineral soils. Electronic Data Information Source (EDIS) SC089, University of Florida, Gainesville, FL. http://edis.ifas.ufl.edu/SC089

Alvarez, J. and Z.R. Helsel. 2001. Economic feasibility of biofuel crops in Florida: Sugarcane on mineral soils. 
Electronic Data Information Source (EDIS) SC090, University of Florida, Gainesville, FL. http://edis.ifas.ufl.edu/ SC090

Rahmani, M. and A. Hodges. 2009. Potential feedstock sources for ethanol production in Florida. Electronic Data Information Source (EDIS) FE650, University of Florida, Gainesville, FL. http://edis.ifas.ufl.edu/fe650

Stricker, J.A., G.M. Prine, D.L. Anderson, D.B. Shibles and T.C. Riddle. 2009. Energy from crops: production and management of biomass/energy crops on phosphatic clay in central Florida. Electronic Data Information Source (EDIS) EH213 (Circular 1084), University of Florida, Gainesville, FL. http://edis.ifas.ufl.edu/eh213

Vermerris, W., C. Rainbolt, D. Wright, and Y. Newman. 2008. Production of biofuel crops in Florida: Sweet sorghum. Electronic Data Information Source (EDIS) AG298, University of Florida, Gainesville, FL. http://edis.ifas.uff. edu/ag298 
Table 1. Estimated per acre costs of cultural activities performed on a one-section (640-acre) farm of one plant crop plus one ratoon crop of sweet sorghum on mineral (sand) soils of South Florida, 2010

\begin{tabular}{|c|c|c|c|c|c|}
\hline Activity & Unit & Rate & \# Times & Price (\$) & \$/Acre/Year \\
\hline \multicolumn{6}{|l|}{ Land preparation } \\
\hline Soil testing and consulting & $\$ /$ acre & & 1 & 1.11 & 1.11 \\
\hline Disking & $\$ /$ acre & & 2 & 15.00 & 30.00 \\
\hline Lime (dolomite) application & $\$ /$ acre & & 1 & 5.00 & 5.00 \\
\hline Lime material & ton/acre & 2.00 & 1 & 28.00 & 56.00 \\
\hline Laser leveling $^{\mathrm{a}}$ & \$/acre & & 0.5 & 60.00 & 30.00 \\
\hline Secondary tillage & $\$ /$ acre & & 1 & 12.00 & 12.00 \\
\hline Total & $\$$ & & & & 134.11 \\
\hline \multicolumn{6}{|l|}{ Planting } \\
\hline Plant drilling & $\$ /$ acre & & 1 & 12.00 & 12.00 \\
\hline Seed cost & lb/acre & 3.00 & 1 & 9.00 & 27.00 \\
\hline Soil insecticide ${ }^{b}$ & $\mathrm{lb} / \mathrm{acre}$ & 3.00 & 1 & 9.00 & 27.00 \\
\hline Total & $\$$ & & & & 66.00 \\
\hline \multicolumn{6}{|l|}{ Cultural activities } \\
\hline Fertilizer application ${ }^{c}$ & $\$ /$ acre & & 2.00 & 6.00 & 12.00 \\
\hline Nitrogen ${ }^{d}$ & $\mathrm{lb} / \mathrm{acre}$ & 90.00 & 2.00 & 0.60 & 108.00 \\
\hline $\mathrm{P} 2 \mathrm{O} 5^{\mathrm{d}}$ & $\mathrm{lb} / \mathrm{acre}$ & 60.00 & 2.00 & 0.60 & 72.00 \\
\hline $\mathrm{K}_{2} \mathrm{O}^{\mathrm{d}}$ & $\mathrm{lb} / \mathrm{acre}$ & 90.00 & 2.00 & 0.60 & 108.00 \\
\hline Micronutrients ${ }^{\mathrm{e}}$ & lb/acre & 15.00 & 2.00 & 0.51 & 15.30 \\
\hline Chemical applications $^{f}$ & Ib/acre & & 2.00 & 4.00 & 8.00 \\
\hline Herbicide $^{g}$ & pt/acre & 1.50 & 1.00 & 2.20 & 3.30 \\
\hline Herbicide $^{h}$ & qt/acre & 2.00 & 1.00 & 1.50 & 3.00 \\
\hline Insecticide & oz/acre & 2.80 & 6.00 & 2.75 & 46.20 \\
\hline Fungicide ${ }^{j}$ & oz/acre & 4.00 & 4.00 & 4.00 & 64.00 \\
\hline Mechanical cultivation ${ }^{k}$ & $\$ /$ acre & & 4.00 & 6.50 & 26.00 \\
\hline Total & $\$$ & & & & 465.80 \\
\hline Miscellaneous' & $\$$ & & & & 66.56 \\
\hline Interest $^{\mathrm{m}}$ & $\$$ & & & & 58.60 \\
\hline \multicolumn{6}{|l|}{ Harvesting activities } \\
\hline Harvesting $^{\mathrm{n}}$ & $\$ /$ ton & 22.50 & 2.00 & 9.00 & 405.00 \\
\hline Deheading & $\$ /$ acre & & 2.00 & 8.00 & 16.00 \\
\hline Transporting $^{n}$ & 10 miles & 22.50 & 2.00 & 93.62 & 187.24 \\
\hline Total & $\$$ & & & & 608.24 \\
\hline Total variable costs & $\$$ & & & & $1,399.34$ \\
\hline \multicolumn{6}{|l|}{ Overhead activities } \\
\hline Supervising and vehicles & $\$ /$ acre & & 1.00 & 10.00 & 10.00 \\
\hline Road and ditch maintenance & $\$ /$ acre & & 1.00 & 5.00 & 5.00 \\
\hline Irrigation $^{\circ}$ & $\$ /$ acre & & 1.00 & 76.00 & 76.00 \\
\hline Taxes and assessments & $\$ /$ acre & & 1.00 & 55.00 & 55.00 \\
\hline Land charge & $\$ /$ acre & & 1.00 & 75.00 & 75.00 \\
\hline Total & $\$$ & & & & 221.00 \\
\hline TOTAL COSTS & $\$$ & & & & $1,620.34$ \\
\hline
\end{tabular}




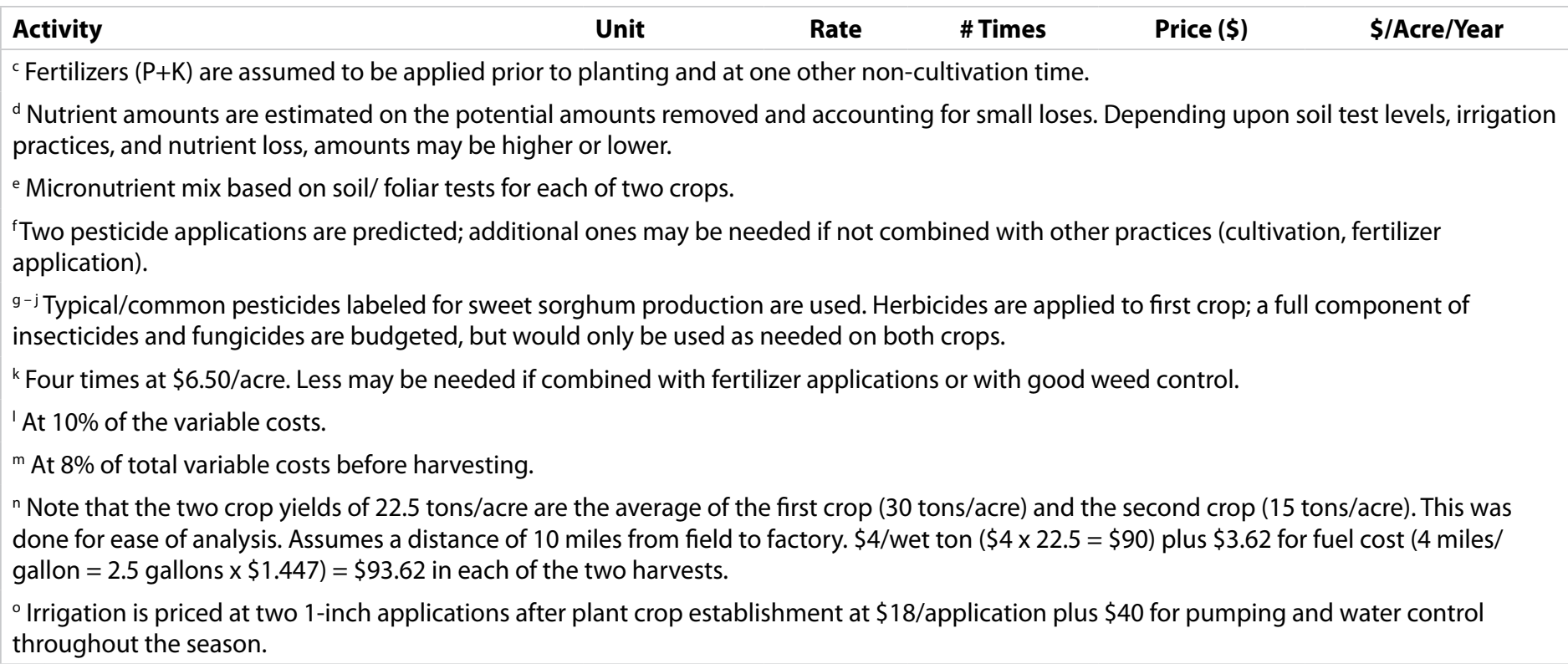


Table 2. Sensitivity analysis of costs (\$) by activity of two (plant and ratoon) sweet sorghum crops per year, with a total biomass yield of 45 tons per acre

\begin{tabular}{|c|c|c|c|c|c|c|c|}
\hline Variation & Land Prep & Planting & Fertilizers & Chemicals & Harvest & Overhead & Total \\
\hline$+15 \%$ & 154 & 76 & 433 & 143 & 699 & 254 & 1863 \\
\hline$+10 \%$ & 148 & 73 & 414 & 137 & 669 & 243 & 1782 \\
\hline$+5 \%$ & 141 & 69 & 395 & 131 & 639 & 232 & 1701 \\
\hline Basic case & 134 & 66 & 376 & 125 & 608 & 221 & 1620 \\
\hline$-5 \%$ & 127 & 63 & 357 & 118 & 578 & 210 & 1539 \\
\hline$-10 \%$ & 121 & 59 & 339 & 112 & 547 & 199 & 1458 \\
\hline$-15 \%$ & 114 & 56 & 320 & 106 & 517 & 188 & 1377 \\
\hline
\end{tabular}


Table 3. Relative profitability of sweet sorghum produced for ethanol at three levels of biomass yields and three levels of ethanol prices

\begin{tabular}{|c|c|c|c|c|c|c|c|}
\hline \multirow{2}{*}{$\begin{array}{l}\text { Biomass } \\
\text { Yield }^{\mathrm{a}}\end{array}$} & \multirow{2}{*}{$\begin{array}{c}\text { Gal/Net } \\
\text { ton }^{b}\end{array}$} & \multirow[t]{2}{*}{$\$ / g a l^{c}$} & \multirow[t]{2}{*}{ Gross Returns } & \multicolumn{2}{|c|}{ Total Costs } & \multirow[t]{2}{*}{ Net Returns } & \multirow[t]{2}{*}{ Breakeven Price } \\
\hline & & & & Growing $^{d}$ & Processing $^{\mathrm{e}}$ & & \\
\hline 58.5 & 14 & 2.90 & 2375 & 1796 & 450 & 129 & 2.74 \\
\hline 58.5 & 14 & 2.25 & 1843 & 1796 & 450 & -404 & 2.74 \\
\hline 58.5 & 14 & 1.80 & 1474 & 1796 & 450 & -772 & 2.74 \\
\hline 45.0 & 14 & 2.90 & 1827 & 1620 & 346 & -139 & 3.12 \\
\hline 45.0 & 14 & 2.25 & 1417 & 1620 & 346 & -549 & 3.12 \\
\hline 45.0 & 14 & 1.80 & 1134 & 1620 & 346 & -832 & 3.12 \\
\hline 31.5 & 14 & 2.90 & 1279 & 1445 & 242 & -408 & 3.83 \\
\hline 31.5 & 14 & 2.25 & 992 & 1445 & 242 & -695 & 3.83 \\
\hline 31.5 & 14 & 1.80 & 794 & 1445 & 242 & -894 & 3.83 \\
\hline $\begin{array}{l}\text { a The basic ca } \\
\text { b Figure used } \\
\text { c Calculated f } \\
\text { d Taken from } \\
\text { e At } \$ 0.55 / \text { gal }\end{array}$ & $\begin{array}{l}\text { ) plus and } \\
\text { st (Frosch } \\
5 \text { prices.cor } \\
\text { culations ir } \\
\text { orris 2008). }\end{array}$ & nterpris & (see Table 1 for so & es of data). & & & \\
\hline
\end{tabular}

